\title{
DAYA TERIMA DAN KANDUNGAN PROTEIN NUGGET KOMBINASI KACANG MERAH (Phaseolus Vulgaris. L) DAN HATI AYAM SEBAGAI PANGAN ALTERNATIF SUMBER PROTEIN UNTUK PENCEGAHAN STUNTING
}

\author{
Astri Puspa Nandini' ${ }^{1}$, Roifah Fajri2 ${ }^{*}$, Ahmad Yani ${ }^{3}$ \\ 1,2,3 Sekolah Tinggi Ilmu Kesehatan Holistik \\ *Korespondensi: Jl. Veteran No. 272 Ciseureuh Purwakarta, Email: roifah@stikesholistic.ac.id
}

\begin{abstract}
ABSTRAK
Latar belakang : Stunting menjadi salah satu permasalahan gizi di Indonesia. Prevalensi stunting di Indonesia sebesar 30.8\% berdasarkan hasil pengukuran TB/U, hasil tersebut terdiri dari pendek $17.1 \%$ dan sangat pendek $12.8 \%$. Pencegahan dapat dilakukan pada masa prakonsepsi dengan memperhatikan asupan protein, sumber protein salah satunya didapatkan dari kacang merah dan hati ayam.

Tujuan : Mengetahui perbedaan daya terima nugget dari berbagai rasio kacang merah dan hati ayam sebagai pangan alternatif sumber protein untuk pencegahan stunting dan mengetahui perbedaan kandungan protein nugget dari berbagai rasio kacang merah dan hati ayam sebagai pangan alternatif sumber protein untuk pencegahan stunting.

Metode : Penelitian ini menggunakan metode Rancangan Acak Lengkap (RAL) dengan lima perlakuan dan tiga kali pengulangan, perbandingan kacang merah dan hati ayam yaitu, 90\%:10\%, 70\%:30\%, 50\%:50\%, 30\%:70\%, 10\%:90\%. Nugget akan diuji daya terima, selanjutnya hasil uji daya terima dilakukan dianalisis secara statistik menggunakan metode Kruskal Waliis dan Mann Whitney. Uji kandungan protein dilakukan dengan metode Kjeldahl dan hasilnya dianalisis secara statistik menggunakan metode One Way anova dan Duncan.

Hasil : Terdapat perbedaan daya terima aroma dan warna nugget dari berbagai rasio kacang merah dan hati ayam. Tidak terdapat perbedaan daya terima rasa dan tekstur nugget dari berbagai rasio kacang merah dan hati ayam. Terdapat perbedaan kandungan protein nugget dari berbagai rasio kacang merah dan hati ayam.

Simpulan : Hasil daya terima menunjukan nugget dengan perlakuan 90\%:10\%, 70\%:30\%, 50\%:50\% merupakan nugget yang disukai panelis. Kandungan protein tertinggi terdapat pada nugget dengan perlakuan 50\%:50\%.
\end{abstract}

Kata kunci : Stunting, nugget, kacang merah, hati ayam, protein.

\section{ABSTRACT}

Background : Stunting become one of the nutritional problems in Indonesia. The prevalence of stunting in Indonesia reach to $30.8 \%$ based on the measurement results of $H / A$, the results consist of short and short $17.1 \%$ and very short $12.8 \%$. Prevention can be done during preconception period with attention to protein intake, a protein source can obtained from red beans and chicken livers.

Objective : To understand the acceptance difference nuggets of various ratios of red beans and chicken liver as an alternative food source of protein for the prevention of stunting and determine differences in protein content nuggets from various ratios of red beans and chicken liver as an alternative food source of protein for the prevention of stunting.

Method : This study used a completely randomized design (CRD) with five treatments and three repetitions, the ratio of red beans and chicken livers ie, 90\%: 10\%, 70\%: 30\%, 50\%: 50\%, 30\%:70\%, 10\%:90\%. The acceptance of nuggets tested with hedonic test and the result were statistically analyzed using Mann Whitney and Kruskal Wallis. Protein content test conducted by the Kjeldahl method and the results were statistically analyzed using 
One Way anova and Duncan.

Result : There are differences in aroma and color acceptance nuggets of various ratio of red beans and chicken livers. There are no significally difference in receptivity taste and texture nuggets of various ratios of red beans and chicken livers. There are differences in the protein content nuggets from various ratios of red bean and chicken liver.

Conclusion : Results showed treatment nugget acceptance of 90\%: 10\%, 70\%: 30\%, 50\%: $50 \%$ is the most preferred nuggets panelist. The highest protein level contained in the nugget with 50\%:50\% ratio of red beans and chicken liver the with $50 \%: 50 \%$ ratio of red beans and chicken liver

\section{Keyword : Stunting, nugget, red bean, chicken liver, protein}

\section{PENDAHULUAN}

Stunting memberikan dampak jangka panjang dan jangka pendek, dampak jangka pendek yang akan di dapat seperti mudah terkena penyakit infeksi, serta gangguan perkembangan kognitif, motorik dan verbal. ${ }^{1}$ Anak yang mengalami stunting diatas usia dua tahun tidak dapat disembuhkan oleh karena itu perlu dicegah.

Pencegahan stunting dapat dilakukan pada saat prakonsepsi yaitu saat pembuahan dimana sel ovum bertemu dengan sperma. Wanita di masa prakonsepsi dapat dikatakan sebagai wanita dewasa atau Wanita Usia Subur (WUS), ${ }^{2}$ rentang usia 15-49 tahun dapat dikatakan sebagai WUS. ${ }^{3}$ Masa prakonsepsi termasuk yang akan mempengaruhi masa kehamilan. ${ }^{4}$ Asupan makanan akan berpengaruh terhadap pertumbuhan dan perkembangan janin. ${ }^{5}$

Gizi makro yang berperan dalam proses perkembangan salah satunya protein. ${ }^{6}$ Protein memiliki fungsi yang berhubungan dengan proses kehidupan, disebabkan protein membantu kerja enzim dan hormon. ${ }^{7}$ Sumber protein dapat berasal dari sumber nabati dan hewani, protein yang bersumber dari nabati salah satunya terdapat pada kacang merah.

Kandungan protein kacang merah dalam 100 gram sebesar 22.1 gram sebesar gram 17.1gram. ${ }^{8}$ Protein nabati mempunyai daya cerna protein yang rendah. Maka dari itu, untuk meningkatkan daya cerna protein yang tinggi perlu ditambahkan dengan sumber protein hewani. Salah satu sumber protein dengan harga yang terjangkau yaitu hati ayam. Hati ayam adalah salah satu organ dari ayam, tetapi hati ayam mudah untuk di temukan di pasaran. ${ }^{9}$ Kandungan protein hati ayam sebesar 27.4 gram/100 gram lebih tinggi dibandingkan hati sapi yang mengandung protein sebesar 19.7 gram/100 gram. ${ }^{8}$

Masyarakat saat ini mengalami perubahan gaya hidup yang berdampak pada konsumsi pangan yang dipilih. ${ }^{10}$ Masyarakat lebih menyukai makanan yang praktis. Berdasarkan penelitian sebelumnya ${ }^{10}$, nugget disukai dari setiap golongan umur mulai dari anak- anak, remaja, dewasa, sampai dewasa akhir dengan usia 36-45 tahun.

Berdasarkan latar belakang yang telah diuraikan peneliti tertarik untuk membuat inovasi makanan nugget dengan kombinasi protein nabati yaitu kacang merah dengan protein hewani yaitu hati ayam. Kombinasi kacang merah dan hati ayam sebagai nugget diharapkan meningkatkan mutu protein nugget. Selanjutnya, nugget akan dilakukan pengujian uji organoleptik dan uji kandungan protein pada nugget kombinasi kacang merah dan hati ayam sebagai pangan alternatif sumber protein.

\section{METODE PENELITIAN}

Penelitian ini menggunakan Rancangan Acak Lengkap (RAL) dengan lima perlakuan dan tiga kali pengulangan. Perlakuan yang digunakan dalam penelitian ini yaitu perbandingan kacang merah dan hati ayam yaitu, 90\%:10\%, 70\%:30\%, 50\%:50\%, 30\%:70\%, 
10\%:90\%. Penelitian ini terdiri dari 6 tahap, yaitu perancangan formula nugget kombinasi kacang merah dan hati ayam, pembuatan produk, uji daya terima, penentuan formula terpilih, uji kandungan protein, dan perhitungan kontribusi \% Angka Kecukupan Gizi (AKG).

Nugget diuji daya terima oleh panelis konsumen sebanyak 30 orang, uji daya terima dilakukan di kampus II STIIKes HOLISTIK Purwakarta dan uji kandungan protein dilaksanakan di Balai Laboratorium Kesehatan Provinsi Jawa Barat. Uji daya terima dianalisis statistik menggunakan metode uji normalitas dan Kruskal Wallis. Hasil kandungan protein dianalisis statistik dengan metode normalitas, One Way anova dan dilanjutkan dengan uji Duncan. Penelitian ini telah mendapatkan ethical clearance dari Komite Etik Penelitian Kesehatan Universitas Pembangunan Negeri Veteran Jakarta dengan nomor B/2220/XI/2019/KEPK.

\section{HASIL}

\section{Daya Terima Nugget Kombinasi Kacang Merah dan Hati Ayam}

Hasil uji daya terima warna, aroma, rasa, tekstur dengan metode uji normalitas didapat hasil yang tidak normal sehingga dilanjutkan dengan uji Kruskal Wallis. Hasil uji Kruskal Wallis pada analisis daya terima parameter warna, didapat nilai $p=0.047$ $(p<0.05)$ yang artinya terdapat perbedaan daya terima warna nugget dari berbagai rasio kacang merah dan hati ayam. Selanjutnya diuji lanjut dengan Maan Whitney, hasil uji Maan Whitney menunjukan perbedaan signifikan F1 dan F2, F1 dan F3, F1 dan F4, F1 dan F5. Hasil uji Kruskal Wallis pada analisis daya terima parameter aroma, didapat nilai $p=0.029$ $(p<0.05)$ yang artinya terdapat perbedaan daya terima aroma nugget dari berbagai rasio kacang merah dan hati ayam. Selanjutnya diuji lanjut dengan Maan Whitney, hasil uji Maan Whitney menunjukan perbedaan signifikan F1 dan F4, F1 dan F5, F2 dan F4, F2 dan F5. Hasil uji Kruskal Wallis pada analisis daya terima parameter rasa, didapat nilai $p=0.703$ $(p>0.05)$ yang artinya tidak terdapat perbedaan daya terima rasa nugget dari berbagai rasio kacang merah dan hati ayam. Hasil uji Kruskal Wallis pada analisis daya terima parameter tekstur, didapat nilai $p=0.368(p>0.05)$ yang artinya tidak terdapat perbedaan daya terima tekstur nugget dari berbagai rasio kacang merah dan hati ayam.

Tabel 1. Hasil Daya Terima Warna, Aroma, Rasa, dan Tekstur

\begin{tabular}{ccccc}
\hline Formula & \multicolumn{4}{c}{ Rerata } \\
\cline { 2 - 5 } & Warna & Aroma & Rasa & Tekstur \\
\hline F1 & $3.66 \pm 0.71 \mathrm{a}$ & $3.93 \pm 0.740 \mathrm{a}$ & $3.7 \pm 0.837$ & $3.53 \pm 0.819$ \\
F2 & $3.16 \pm 0.87 \mathrm{~b}$ & $3.86 \pm 0.776 \mathrm{a}$ & $3.83 \pm 0.986$ & $3.66 \pm 0.802$ \\
F3 & $3.13 \pm 0.68 \mathrm{~b}$ & $3.73 \pm 0.980 \mathrm{ab}$ & $3.86 \pm 1.008$ & $3.63 \pm 0.890$ \\
F4 & $3.13 \pm 0.81 \mathrm{~b}$ & $3.4 \pm 0.770 \mathrm{~b}$ & $3.56 \pm 1.073$ & $3.46 \pm 0.900$ \\
F5 & $3.13 \pm 0.90 \mathrm{~b}$ & $3.3 \pm 0.877 \mathrm{bc}$ & $3.63 \pm 0.928$ & $3.23 \pm 0.971$ \\
\hline$p$ & 0.047 & 0.029 & 0.703 & 0.368 \\
\hline
\end{tabular}

Keterangan : huruf yang berbeda pada kolom yang sama menunjukkan perbedaan yang signifikan

\section{Penentuan Formula Terpilih}

Tabel 2. Hasil Pembobotan Daya Terima menggunakan Metode MPE

\begin{tabular}{|c|c|c|c|c|c|c|}
\hline \multirow[b]{2}{*}{ Formula } & \multicolumn{5}{|c|}{ Atribut } & \multirow[b]{2}{*}{$\begin{array}{c}\text { Daya Terima } \\
\text { Keseluruhan }(\%)\end{array}$} \\
\hline & $\begin{array}{l}\text { Warna } \\
(15 \%)\end{array}$ & $\begin{array}{c}\text { Aroma } \\
(20 \%)\end{array}$ & $\begin{array}{l}\text { Rasa } \\
(35 \%)\end{array}$ & $\begin{array}{l}\text { Tekstur } \\
(30 \%)\end{array}$ & Total & \\
\hline
\end{tabular}




\begin{tabular}{llllllc}
\hline F1 & 0.55 & 0.73 & 1.29 & 1.10 & 3.67 & $73.4 \%$ \\
F2 & 0.54 & 0.72 & 1.26 & 1.08 & 3.6 & $72 \%$ \\
F3 & 0.53 & 0.71 & 1.25 & 1.07 & 3.56 & $71.2 \%$ \\
F4 & 0.50 & 0.67 & 1.18 & 1.01 & 3.36 & $67.2 \%$ \\
F5 & 0.49 & 0.66 & 1.16 & 0.99 & 3.3 & $66 \%$ \\
\hline
\end{tabular}

Keterangan : $\mathrm{F} 1=$ Perbandingan kacang merah dan hati ayam $90 \%: 10 \%$

$\mathrm{F} 2=$ Perbandingan kacang merah dan hati ayam 70\%:30\%

$\mathrm{F} 3=$ Perbandingan kacang merah dan hati ayam 50\%:50\%

$\mathrm{F} 4=$ Perbandingan kacang merah dan hati ayam 30\%:70\%

$\mathrm{F} 5=$ Perbandingan kacang merah dan hati ayam 10\%:90\%

\section{Kandungan Protein Nugget Kombinas Kacang Merah dan Hati Ayam}

Data uji kandungan protein diuji menggunakan normalitas menghasilkan data yang normal. Kemudian dilanjutkan dengan uji oneway anova untuk mengetahui terdapat perbedaan anatara formula. Hasil oneway anova didapatkan nilai $\mathrm{p}=0.011$ sehingga $\mathrm{p}<0.05$ yang artinya terdapat perbedaan kandungan protein nugget dari berbagai rasio kacang merah dan hati ayam perbedaan rasio kacang merah dan hati ayam. Selanjutnya dilakukan uji Duncan untuk mengetahui formula mana saja yang terdapat perbedaan signifikan, hasil uji Duncan yang memiliki perbedaan F1 dan F3, F2 dan F3.

Tabel 3. Kandungan Protein Sampel Terpilih

\begin{tabular}{ccc}
\hline Perlakuan & Kadar Protein $\%$ & $p$ Value \\
\hline F1 & $11.62 \pm 0.44^{\mathrm{a}}$ & 0.011 \\
F2 & $11.60 \pm 0.35^{\mathrm{a}}$ & \\
F3 & $12.83 \pm 0.31^{\mathrm{b}}$ & \\
\hline
\end{tabular}

Keterangan: $\quad$ Notasi yang berbeda menunjukan perbedaan

\section{PEMBAHASAN}

\section{Daya Terima Nugget Kombinasi Kacang Merah dan Hati Ayam}

Warna nugget yang dinilai oleh panelis yaitu nugget bagian dalam, warna nugget kombinasi kacang merah dan hati ayam pada penelitian ini coklat gelap. Warna bagian dalam dari nugget berbedabeda disebabkan oleh perbedaan rasio kacang merah dan hati ayam. Kacang merah dan hati ayam mempunyai kandungan protein yang termasuk kedalam komponen reaktif pada bahan makanan sehingga dapat beraksi dengan gula pereduksi, lemak, dan produk oksidasi sehingga memberikan warna yang lebih gelap. ${ }^{11}$ Nugget dengan perlakuan 90:10\% merupakan warna yang paling disukai oleh panelis.

Panelis menilai aroma nugget dengan cara mencium aroma nugget kombinasi kacang merah dan hati ayam setelah dari bagian luar dan dalam nugget. Nugget dengan komposisi kacang merah lebih banyak, akan menghasilkan aroma yang tidak amis sedangkan nugget dengan komposisi hati ayam yang lebih banyak, akan menghasilkan aroma ciri khas hati ayam yang anyir sehingga nugget dengan perlakuan 90:10\% merupakan aroma yang paling disukai oleh panelis. Rasa dapat dipengaruhi oleh bumbu-bumbu yang digunakan dalam pembuatan nugget kombinasi kacang merah dan hati ayam.12 Penambahan hati yang lebih banyak memberikan pengaruh pada rasa pahit, sehingga nugget dengan perlakuan 50\%:50\% merupakan rasa yang paling disukai oleh panelis.

Nugget dengan komposisi kacang merah lebih banyak, akan menghasilkan tekstur nugget yang lebih padat. Nugget dengan komposisi hati ayam yang lebih banyak, akan menghasilkan tekstur nugget yang lebih lembek, sehingga nugget dengan perlakuan 70\%:30\% merupakan tekstur yang paling disukai 
oleh panelis. Sejalan dengan penelitian Rukmi (2009),13 semakin banyak penambahan kacang merah sehingga berpengaruh pada tekstur menjadi lebih keras. Sedangkan penambahan hati ayam lebih banyak menghasilkan tekstur yang lembek dan mudah untuk patah. Kandungan protein pada hati ayam memiliki daya ikat air atau Water Holding Capacity (WHC). Fungsi WHC merupakan cara daging dalam mempertahankan air pada saat diberikan tekanan atau pengolahan seperti pemotongan, penggilingan dan pemanasan. ${ }^{14}$ Penambahan hati ayam lebih banyak akan berpengaruh pada tekstur yang lembab (lembek) karena kandungan air menjadi lebih tinggi. ${ }^{9}$

\section{Penentuan Formula Terpilih}

Penentuan formula terpilih dengan metode MPE dapat menunjukan urutan formula tepilih dilihat dari total tertinggi, total F1 menunjukan urutan pertama, total F2 menunjukan urutan kedua dan total F3 menunjukan urutan ketiga. Setelah mendapatkan 3 formula terpilih, kemudian dilakukan uji kandungan protein.

\section{Kandungan Protein Nugget Kombinasi Kacang Merah dan Hati Ayam}

Hasil analisis kandungan protein menunjukkan bahwa perlakuan F3 yaitu nugget dengan perbandingan kacang merah dan hati ayam 50\%:50\% merupakan nugget dengan kandungan protein tertinggi. Nugget termasuk ke dalam makanan selingan, makanan selingan merupakan makanan yang dikonsumsi diantara waktu makan utama dengan jangka waktu 2-3 jam sebelum makanan utama. ${ }^{15}$ Syarat kebutuhan makanan selingan $10-15 \%$ dari total kebutuhan energi dan protein dalam satu hari. Kontribusi protein nugget kombinasi kacang merah dan hati ayam terhadap AKG WUS usia 18 tahun 19-21 tahun sebesar 17.84-21.83\%. Berdasarkan syarat makanan selingan protein nugget kombinasi kacang merah dan hati ayam, dapat di katan tinggi, karena protein yang dihasilkan lebih besar dari syarat makanan selingan.

\section{SIMPULAN}

1. Hasil daya terima menunjukan nugget dengan perlakukan 90\%:10\%, 70\%:30\%, 50\%:50\% merupakan nugget yang disukai panelis.

2. Kandungan protein tertinggi terdapat pada nugget dengan perlakuan 50\%:50\%.

\section{DAFTAR PUSTAKA}

1. Kementrian Kesehatan Republik Indonesia. Cegah Stunting Dengan Perbaikan Pola Asuh dan Sanitasi. Jakarta ; Direktorat Jendral. 2018.

2. Dieny, Fillah Fithra, Rahadiyati Ayu \& Kurniawati Marfu'ah Dewi. Gizi Prakonsepsi. Jakarta Timur: Bumi Medika. 2019.

3. Kementrian Kesehatan Republik Indonesia. Situasi Kesehatan Reproduksi Remaja, Info Data dan Informasi. Jakarta.2015.

4. Hubu N, Nuryani N, Hano YH. Pengetahuan, Asupan Energy Dan Zat Gizi Berhubungan Dengan Kekurangan Energy Kronis Pada Wanita Prakonsepsi. Gorontalo Journal Of Public Health. 2018 Apr 19;1(1):015-23.

5. Syari M, Serudji J, Mariati U. Peran Asupan Zat Gizi Makronutrien Ibu Hamil Terhadap Berat Badan Lahir Bayi Di Kota Padang. Jurnal Kesehatan Andalas. 2015 Sep 1;4(3).

6. Ekweagwu E, Agwu AE, Madukwe E. The Role Of Micronutrients In Child Health: A Review Of The Literature. African Journal of Biotechnology. 2008;7(21).

7. Katili AS. Struktur Dan Fungsi Protein Kolagen. Jurnal Pelangi Ilmu. 2009 May 5;2(5).

8. Kementrian Kesehatan RI (Direktorat Jendral Kesehatan Masyarakat). Tabel Komposisi Pangan Indonesia. Jakarta. 2017.

9. Malichati AR, Adi AC. Kaldu Ayam Instan dengan Substitusi Tepung Hati Ayam sebagai Alternatif Bumbu untuk Mencegah Anemia. Amerta 
Journal of $\mathrm{Holistic}$ and $\mathrm{Health} \mathrm{Sciences}$ Vol.3, No.2, Juli-Desember 2019 | 88

Nutrition. 2018 Mar 12;2(1):74-82.

10. Prastiwi WD, Santoso SI, Marzuki S. Preferensi Dan Persepsi Konsumsi Produk Nugget Sebagai Alternatif Konsumsi Daging Ayam Pada Masyarakat Di Kecamatan Secang Kabupaten Magelang. Agromedia. 2017;35(1)

11. Apriyana I. Pengaruh Penambahan Tepung Kepala Ikan Lele (Clariassp) Dalam Pembuatan Cilok Terhadap Kadar Protein dan Sifat Organoleptiknya (Doctoral dissertation, UniversitasNegeri Semarang). 2013.

12. Wulandari E, Suryaningsih L, Pratama A, Putra DS, Runtini N. Karakteristik Fisik, Kimia dan Nilai Kesukaan Nugget Ayam Dengan Penambahan Pasta Tomat (Effect of Tomatos Paste to Physicochemical and Sensory Characteristics Chicken Nuggets).
Jurnal Ilmu Ternak Universitas Padjadjaran. 2016;16(2).

13. Rukmi AS. Kadar Serat, Kadar Kalsium, Tekstur Dan Organoleptik Produk Ekstrusi Jagung Dengan Substitusi Kacang Merah. Penelitian Ilmu Gizi. Undip. Semarang. 2009.

14. Suwiti NK, Susilawati NN, Swacita IB. Karakteristik Fisik Daging Sapi Bali Dan Wagyu. Buletin Veteriner Udayana. 2017:125-31.

15. Pradipta Oj. Pengolahan Koro Pedang Putih (CanavaliaEnsiformis), Ubi Cilembu (Ipomoea Batatas), Dan Apel Fuji (MalusSylvestris) Sebagai Bahan Snack Bar (Doctoral dissertation, Unika Soegijapranata Semarang). 2016 
Journal of Holistic and Health Sciences Vol.3, No.2, Juli-Dese m b e r 2019 | 89 